\title{
UNDERSTANDING CYCLE TOURISM EXPERIENCES AT THE TOUR DOWN UNDER
}

\begin{abstract}
Sport tourism experiences are subjective and emotional, laden with symbolic meaning. This study explores the experiences of participants who adopted the multiple roles of both an active participant and event spectator, within the parameters of one chosen sporting event. A professional cycling race event, the Tour Down Under (TDU) in South Australia was chosen for this investigation, and twenty face-to-face individual interviews were conducted with cycle tourists. The three main themes emerging from the data were the interaction of people and temporary spaces on a sport tourism 'stage'; the co-creation of authentic personal experiences and meanings; and identity reinforcement and the development of a sense of belonging. Consequently, a model for understanding sport event tourism experiences is proposed. The findings suggest that providing tourists with authentic and memorable experiences lies at the heart of what constitutes sport tourism. Whilst the results demonstrate that cycling events provide the individual with a sense of belonging or membership to a wider social group, they also illustrate that there is a continued need for more focused and nuanced approaches towards understanding sport tourism experiences that reflect the ever-increasing diversity and complexity of the interaction between sport, events and tourism.
\end{abstract}

\section{Keywords}

Experiences, cycle tourism, co-creation, identity, belonging 


\section{INTRODUCTION}

One particular area that sport and tourism have in common is that they provide consumers with experiences. An understanding of the ways in which tourists experience the places and people they visit and the activities they undertake, is therefore fundamental to the study of the consumption of sport tourism (Shipway \& Stevenson, 2012). Active participation in sporting activities is one of many ways in which people choose to experience places and people as part of tourism practices. However, the relationship between the sporting and travel aspects of sport tourism is complex. Previous research has indicated that sport tourism experiences are subjective and emotional, laden with symbolic meaning (Shipway \& Jones, 2008). As sport tourism has continued to expand in both scale and scope, and as sport tourists' needs and expectations have become more diverse and complex (Shipway \& Fyall, 2012), so too have their sport tourist experiences.

Despite the recent emergence of studies exploring experiences, there is a need to further expand theory driven understandings of active sport tourism experiences by providing empirical insights within the context of international sports events. Further, sports tours that create hybrid experiences combining active sport tourism with passive spectator experiences at major sport events, such as visits to the Tour de France (Lamont \& McKay, 2012), have not been widely examined. To further assist with academic progression from description to explanation (Weed, 2006; Shipway \& Kirkup, 2012), this research at the Tour Down Under (TDU), an international professional cycling event in South Australia, aims to provides a deeper understanding of the experience associated with cyclists who adopted multiple roles of both active participants and event spectators at a sporting event.

The TDU has been held annually in the city of Adelaide, South Australia since 1999, and is the first road event of the Union Cycliste International (UCI) world tour series. The main focus of the event is six professional cycling race stages held over six consecutive days throughout the state of South Australia. The TDU also includes a number of associated events and activities such as street parties, charity challenges and recreational rides for amateur cyclists. It attracts not only professional riders of international teams from all over the world, but also amateur cyclists who are serious about cycling, casual cyclists, and fans of cycling races. The 2014 TDU attracted more than 760,400 people, including 40,000 interstate and 
international visitors, and has become the largest cycling event in the southern hemisphere (Events South Australia, 2014; Tour Down Under, 2014).

\section{SPORT TOURISM EXPERIENCES \& CYCLE TOURISM}

\section{Perspectives on sport tourism experiences}

Both Gibson (2005) and Weed (2006) have previously argued that given the relative infancy of sport tourism as a subject area, there had been a slow development of a coherent and usable body of knowledge, and studies on sport tourism were generally descriptive, and failed to address issues such as why the event sport tourist experience was enjoyable, or why participants liked to repeat the experience (Shipway \& Kirkup, 2010). Similarly, in the context of the sport events literature, Shipway and Jones (2008) argued that few studies explore the qualitative experiences of active participants. In response to these calls in the literature between 2005 and 2010, the volume of scholarly work on sport tourism experiences has significantly increased over recent years (Coghlan, 2012; Rickly-Boyd, 2012a; Houge Mackenzie \& Kerr, 2012; Hallmann, Feiler, Muller \& Breuer, 2012; Miller, 2012; Kirkup, 2012). These more recent studies utilised different forms of qualitative research methods, and the recent introduction of more diverse theoretical perspectives also brought with it diversity in methodological approaches.

The work of Coghlan (2012), which she acknowledged was located at the boundaries of cycle tourism, sports and charity events, called for a deeper understanding of the nuances that permeate participants' experiences of certain events, which includes cycling events such as the TDU. Coghlan (2012) argued that her own qualitative approach was able to draw out aspects of the sport tourism experience that were less readily available through quantitative techniques. Through diary entries and qualitative methods of enquiry, she was able to explore both the manifest and latent experiences of the cycling experience. Her study illustrated the complexities around understanding how cyclists perceive and interpret their own experiences. Similarly, in a study on understanding event experience of active sport tourists, Miller (2012) focused on the sport of triathlon and highlighted firstly the importance of a sense of camaraderie amongst the Ironman community that she interviewed, and secondly the sense of place that participants felt, whereby the emphasis was also on the challenge and experience 
that resulted from the geographical features of the host destination or region where the event took place.

Rickly-Boyd (2012a), in her study of lifestyle climbing, emphasised the bodily practice and flow of active participation and the camaraderie that evolves from authentic experiences, which are performative and that can also assist with the (re) discovery of a sense of self. Her work emphasised the need to explore feelings, sensations, relationships and the sense of self that comes from the performance of sport tourism. Within the tourism literature, Pearce and Moscardo (1986) were among the first tourism academics to indicate that authenticity can emerge from experiences with both people and places, which also supports many of the emerging concepts linked to sport tourism development (Weed \& Bull, 2004). Rickly-Boyd (2012b) suggested that authentic experiences are about collectively performing and experiencing the journey.

In addition, there exist selective studies of sports spectators within the consumer behaviour literature which recognised experiences as having emotional, symbolic and transformational significance for the individual (Kapferer, 1997; Morgan, 2006). The experience is created by the interaction between activities (for example, cycling), and places (for example, the cycling event), plus the internal motivations and meanings brought by the participant (the cyclist). In the context of this study on cycle tourism, this interaction is partly a social one that takes place as people converge on the TDU, but also a psychological one that takes place in the heads of the cyclists as they interpret their impressions of a place and culture (Morgan, 2007).

Through his analysis of sports fans in New Zealand, Morgan (2007) stressed the hedonistic aspects of the sport tourism experience. Morgan (2006) grouped the internal elements of an experience under three inclusive headings, which can also be interpreted within a cycle tourism related environment. These are personal benefits of hedonistic enjoyment (for example novelty or escape) and achievement (for example, growth through overcoming challenges); secondly social interaction which can lead to a sense of communitas; and thirdly, the wider symbolic meanings derived from personal narratives and shared cultural values. In both of Morgan's studies, the social aspect was a recurring theme and he also stressed the importance of the third element of the event experience, meanings and values. Likewise, Silk (2005) suggests that sport in itself carries with it meanings derived from family, career and 
lifestage, and cultural upbringing. Morgan concluded his own studies by indicating that the extent to which a sport tourism experience is unique and memorable lies in the internal personal satisfactions and meanings derived from the participant. In the context of this study, this analysis will examine the experiences of cycle tourists attending the TDU.

\section{Cycle tourism experiences}

According to Lamont (2014a), early published research on cycling and tourism had lacked theoretical foundations and led to a descriptive and applied body of literature. However, he suggested that more recent developments in cycle tourism literature had seen the emergence of studies that had sought to better understand cycle tourists' experiences, along with an emerging stream of research that provided a broader theoretical and methodological horizon to the study of cycle tourism. Lamont cited several studies (Coghlan, 2012; Cox, 2012; Fullager, 2012; Lamont \& McKay, 2012;) as examples of cycle tourism research that had utilised various research approaches that have yielded rich, qualitative insights into the link between cycling and tourism experiences. In an alternative study, Ritchie, Tkaczynski and Faulks (2010) provided a deeper understanding of the motivations and behaviours of cycle tourists in both Victoria and South Australia through applying the concept of enduring involvement, and in doing so, established that cycle tourists were not a homogeneous group.

Lamont (2014b) also suggested that authenticity was potentially a revealing lens for examining sport tourists' encounters with sport landscapes, events and related attractions. Once again, he continued to argue that there was a lack of empirical research about the processes through which sport tourism objects, sites or events are authenticated. In relation to exploring cycle tourism experiences, Lamont (2014a) also indicated that a new stream of research examining cycle tourists' experiences from sociological and social psychological perspectives had recently emerged. In summary, Lamont (2014a) postulated that research on the link between cycling and tourism had increased significantly since 2010, due to various factors including a realisation amongst researchers that cycle tourism is receptive to multidisciplinary inquiry, particularly approaches that focus inward on the cyclist. He argued that studies have now moved away from description and towards explanation, as is the case in the broader sport event tourism experiences literature (Shipway \& Stevenson, 2012). It is hoped that this paper, containing insights into the TDU will also help to further extend existing literature on cycle tourism experiences. 


\section{Cycle tourism in Australia}

There is recognition of a growing cycle tourism market in Australia. For example, a report by Faulks, Ritchie and Fluker (2007) sought to map the size and scope of the industry yet also highlighted the dearth of research in this area. Previous studies had also seen a focus on South Australia as a cycle tourism destination. For example an industry report by Faulks, Ritchie, Brown and Beeton (2008) sought to identify perceptions of South Australia as a destination for cyclists. Faulks et al. (2008) found that that the most important destination attributes within South Australia included scenery, bike friendly accommodations, cycling events like the Tour Down Under (TDU), landmarks and iconic destinations, attractive climatic conditions, and the quality of roads. Importantly, the TDU, the chosen sport event under investigation for this paper was rated highly by respondents in the Faulks et al. (2008) paper.

Following various attempts to define cycle tourism (Lumdson, 1996; Ritchie, 1999), and given the mix of active cycling and spectating associated with the TDU, the definition offered by South Australian Tourism Commission (2005, p.3) is accepted as most appropriate for this study:

'Cycle tourism visits are considered to be the purpose of holidays, recreation, pleasure or sport; and to include either overnight stays or day trips to other tourism regions during which the visitor either engages in active cycling, or is a spectator at a cycling event.'

Lamont (2009) argues that various definitions are flawed; however for the purpose of the Tour Down Under (TDU), the South Australian Tourism Commission definition acknowledges that cycle tourism may extend to competitive cycling, and is therefore the first to include spectators at cycling events like the TDU. Lamont (2009) himself suggests that this very definition was postulated with the inclusion of spectators to allow economic impact measurements attributable to cycle events in South Australia, such as the TDU. He also cites Blamey (1997, p.15) who acknowledges that 'different definitions will be suited to different circumstances', and for this reason, this definition is the best suited for this study. In summary, there is an increasing body of emerging research on cycle tourism, cycle tourism 
experiences, and sport tourism experiences more generally, and this paper aims to further contribute knowledge and insight towards understanding sport tourism experiences that reflect the ever-increasing diversity and complexity of the interaction between sport, events and tourism.

\section{METHODOLOGY}

A convenience approach was employed to recruit respondents for face-to-face interviews. Individuals who attended the 2014 TDU and participated in any cycling activities during the 2014 TDU were asked to participate in the interviews on an availability basis (King, 2012). Those cycling activities primarily involved cycling sections of the TDU course either prior to, or after the main professional event. Cycle tourists were recruited during the event at a range of locations including the start and finish lines of each stage, the Tour Village (the hub of the event), out on the race route at selected strategic points, and other cycling events held in Adelaide during the event week such as criteriums and social events. Consequently, interviews took place in a range of outdoor event spaces such as bars, cafes or grassed areas.

A total of thirty five semi-structured interviews were conducted as part of a wider study on the event and the length of the interviews varied from thirty to forty five minutes. However, fifteen of this sample were from the Adelaide area and did not fit the criteria of cycle tourists, and as such, for the purpose of this study they were discounted. Therefore the thoughts and experiences of the remaining twenty cycle tourist respondents were analysed as shown in Table 1. All the cyclists interviewed for this study adopted multiple roles as both active participants, cycling sections of the road race course and the surrounding routes, and the role of spectators stopping at various locations around the course to watch and support the professional riders and teams competing in the main Union Cycliste International (UCI) event.

\section{Insert Table 1 here}

The interviews centred on the cyclists' experiences during the TDU, and whilst some questions were pre-planned, the responses dictated further questions and generated additional ideas and contrasting formulation of the questions over the course of the interview (Jones et al, 2013). However, the researchers did follow an interview guide to a greater extent in order 
to achieve the specific aim of understanding sport tourist experiences and eliciting the participants' thoughts and feelings (Shipway \& Jones, 2007). Additional data collection through the form of participant observation was also undertaken, focusing on the physical feelings, thoughts, emotions and emotional recall of the participants (Shipway \& Jones, 2008).

Analysis of the interview data was conducted using an inductive approach on the basis of thematic analysis to identify the meanings that cyclists constructed about their experiences. As such, the study adopted an inductive 'bottom up' rather than in a deductive or 'top down' approach. This approach meant that the themes identified were led by the data themselves and were not driven by a pre-identified theoretical interest in cycle tourism. It is suggested that this approach towards inductive analysis is therefore a process of coding the data without trying to fit it into a pre-existing coding frame, or any analytic preconceptions (Holloway \& Wheeler, 2010). As such, the chosen approach gave experience primacy (Holloway \& Todres, 2003). It prioritised understanding the cyclists everyday experience of reality at sports events, in great detail, in order to gain an understanding of the sport tourism phenomenon in question (Shipway \& Jones, 2007).

Upon concluding the interviews, the next step was to transcribe the recorded voice interviews verbatim followed by a multi stage analysis of the data. Research team members first explored the transcripts individually to derive the general structures and patterns and determine a set of initial codes. Subsequently, the team members met to discuss their interpretations after which codes were defined and grouped into themes and a final coding scheme was developed and applied across the data set. Rather than following specific themes indicated by previous work, this paper aims to offer new perspectives through an inductive qualitative approach whereby the discussions are data led. Consequently, a dialogue with the literature relevant to the study will now occur throughout.

\section{RESULTS}

The results indicate that the TDU provided a distinctive opportunity in which cycle tourists were able to use sport event spaces to further develop their identity associated with the particular activity of cycling. The cyclists in this study adopted multiple roles of both active participants and event spectators, within the parameters of one chosen sporting event. All 
respondents chose to cycle sections of the designated course prior to, or after watching the main professional elite event. The three emerging themes of this study include, firstly the unique interaction between participants and temporary cycling places and spaces on a sport tourism 'stage'; secondly, an opportunity for the co-creation of authentic personal experiences and meanings; and thirdly, an avenue for identity reinforcement and the development of a sense of belonging.

\section{The sport tourism stage}

The findings below highlight the central importance of space, and how travel to participate in cycling events like the TDU as both a participant and spectator provides a setting for cyclists to interact with one another, based on the very act of cycling. The TDU contains all the necessary ingredients of the Pine and Gilmore (1999) recipe for experience management. Each daily stage of the cycling event was a 'set' decorated with cycling signs and symbols, from the start and finish banners to the free gifts that sponsors freely distributed to spectators at the event. The various merchandising outlets in the 'Tour Village' also provided spaces where cyclists were able to purchase products associated with the event and this merchandising served the dual effect of emphasising similarities between the self and other in-group members and also emphasising the differences between the self and out-groups members, as was also illustrated in the work of Shipway and Jones (2007) in their study of distance runners. The merchandising associated with the TDU allowed the cyclists to present themselves in a manner that allowed them to be recognised by other cyclists in the in-group. Andy expressed his own thoughts on the importance of the sport 'stage', the programme, and the ability to interact with other cyclists:

'I just think Adelaide is a beautiful city and it's amazing to ride here, and meet other cyclists. The road surfaces are good and the TDU is just a well organised event. I mean I've been to the Tour De France and you'll never get near to the riders and the tour villages or the finish lines like you do here, and so it's amazing for us riders to get the chance to do this.'

Paul's comments below were typical with his assessment of the importance of being able to experience the route of the TDU as an active cyclist and how this allowed him to generate certain stories which demonstrated a level of skill, knowledge or ability in cycling which 
would be recognised amongst his peers within the cycling community. His comment highlights the importance of these event spaces and suggests that, similarly to the work of Shipway and Jones (2008), this unique story telling about cycle tourism experiences also serves to reinforce the individual's sense of identity:

'You are actually able to almost go (virtually) against the pros. Like on Tuesday before the main race, we did Shepherds Hill and I rode over there from the city with one of my mates and he said 'I'm feeling good today'. I said go as hard as you can up Shepherds Hill. A bit later the pros went through and he was faster than any of the pros up there.'

Several respondents in this study indicated that certain 'stages' and places within cycling events like the Giro D'Italia, La Vuelta, or the Tour De France in Italy, Spain and France respectively are 'sacred places' for cyclists. This affection for cycling places may not only lie in the physical aspects like the courses and routes that comprise each stage of the event, but they could also lie in the memories of fellow cyclists who have rode these routes in the past, and the stories that they tell about these events in the cycling social world. Urry (2002) contended that tourists often travel to iconic destinations and resorts in order to collect 'places'. Whilst Urry refers to this as the 'tourist gaze', several cyclists indicated that one of the greatest rewards whilst at the TDU was to enjoy their own 'cycling gaze' at the scenery that passes by whilst they were riding sections of the course throughout South Australia. This was the part of the day, or even part of their holiday, that they couldn't do without. The scenery and places were Bruce's most memorable experience:

'Yeah, I think South Australia is the cycling capital. Melbourne's good; Sydney forget it with the roads and the traffic - you die, as everyone drives. However, in Adelaide, I don't know - I mean; have you been up in the hills? There are some beautiful rides and some nice little quiet roads through the trees, and it's just beautiful for riding. I would never have known about the lovely rides in the hills there. We went to Hahndorf on Wednesday and we rode up there and watched the race and had lunch there too - it was wonderful.'

Further evidence was found for this, as noted by Keith, reinforcing the earlier observations, in relation to the atmosphere experienced at the TDU: 
'South Australia and Adelaide are showcased on TV too. The helicopter shots are great. It's a beautiful state and a beautiful place to ride a bike. It's god's country and absolutely beautiful. Just going along - gum trees lining the road.'

For John, his comments were concise; however they appeared to support the underlying thoughts of the vast majority of the cycle tourists interviewed when he stated 'The whole tour is just such a good postcard for what the state has on offer for tourism. It's just brilliant.'

The findings suggest that meaning is created by the interaction of the cyclist and their understanding of the historical and cultural significance of certain cycling events and spatial locations. Taylor (2001, p. 10) suggests that from within the tourism context, visitors are 'driven by the need for experiences more profound than those associated with the "shallowness of their \{modern\} lives". The TDU offers a special time and space where cyclists were able to construct their own experiences by interacting with the event programme, setting, and other sport tourists and create their own personal values and meanings (Berridge, 2012; Getz, 2007; Lee et al., 2014).

\section{Co-creating 'authentic' personal experiences and meanings}

Secondly, the findings illustrate how the TDU facilitated authentic experiences for cycle tourists through co-creative processes which enabled participants to develop their own personal stories during the time of the event, through interacting with the event setting, programme and other cycle tourists. Study respondents identified a distinct atmosphere at cycling events which emerged through their experience of direct participation (cycling) around the course prior, during, or after the professional elite race and by watching or supporting the event from the sidelines, crucially alongside other cyclists with whom they shared these experiences. The opportunity to observe and meet professional cyclists from around the world was one of the particular attractions which contributed to this atmosphere and sense of occasion: This point was noted by Pam:

'Yeah, but watching the cyclists and seeing the TDU grow as an event means we get the better quality of riders coming in. When it first started all the teams would send their junior riders out, but now you're getting the top riders like Frank Schlek and 
Richie Porte and Cadel (Evans) and people like that are riding. It makes it a top quality event; it's not second rate.'

John was quick to point out the accessibility of these elite riders to those who visited the TDU contributed towards his own positive experiences:

'The Tour Down Under is really accessible to the riders. They go probably four times as fast as I do, but it's good to understand what they do and that they've probably already ridden $140 \mathrm{~km}$ 's.'

Ian and his wife were fortunate enough to come into direct contact with perhaps the most high profile elite cyclist participating in the TDU. Ian reflected on their experience:

'We probably had the experience of a lifetime yesterday. My partner and I, at the end of the race, we were in Campbelltown at the finish and we saw Cadel (Evans). So, he was on his own and my partner said 'Do you mind if we ride with you back to town?", and he said, "No, that's fine". So, when he was ready we rode back to the Hilton hotel in Adelaide where he was staying. He chatted to my partner the whole way back, and we rode for 15 kilometres with him - just the two of us. I've got a photo. We put it on facebook, and we emailed all our friends.'

During the various stages of the TDU, held over six days, it was apparent that the atmosphere at the TDU was perceived as a unique and authentic tourism experience. In their study of the Tour de France, Lamont and McKay (2012, p.323) emphasised that for many cycle tourists the attraction of that particular high profile event was the opportunity to engage in 'authentic, individualised, self-actualising and mentally and physically challenging experiences'. As Lamont (2014b) also suggests, the co-presence with an event such as the TDU can contribute towards a 'buzzing' carnivalesque atmosphere that is perhaps similar to the experiences of roadside spectators at the Tour De France. Susan had a couple of observations on how she felt about the atmosphere at the TDU:

'I just like the whole atmosphere, wherever you go, in any of the towns where they start or finish it. It's just a big carnival. You also get to go down to the Tour Village in 
Adelaide city centre and everyone's into it; it's a real happy good feel about it all. We like the way it travels around to different towns and it's just a festival of the wheel.'

Andy held similar views to those of Susan with regards to the atmosphere and how this made the event both authentic and somewhat unique:

'I think we all get hooked up in this carnival feeling and it's just a happy feeling, where we are all together, and we are all just good friends. We cycle all through the year at home and here it's just nice to cycle with other people and also amongst all these international cyclists. It's a good buzz - it's a good atmosphere around the whole of the city when the TDU's here, with all the pro riders here.'

The very act of cycling around the course and being both an active sport tourist and an event spectator on the same day appeared to enhance the authenticity of the experience of the respondents. It was Lamont and McKay (2012) who previously identified that the ability for cycle tourists to be able to cycle on some of the roads comprising the Tour de France further evoked feelings of authenticity. Supporting this notion, the opportunity to ride and meet other cyclists (both amateur and professionals) was a primary appeal of the event, according to Clive:

'Yeah, I suppose if you do cycle you feel more a part of it; you're not just a watcher, you're a participant as well and you appreciate the skills and toughness involved in riding the event for the pros. People who have cycled the big tours in Europe say that the TDU is the most accessible tour they've ever been to, in terms of seeing the riders, meeting the riders and training with the riders.'

Palmer (2010) also illustrated the uniqueness of cycling events because of the closeness of spectators and competitors. This appeared to be even greater in the context of the TDU and this was the case for Shaun:

'It's good to ride in the same hills as the pros. I mean, you get a bit of an understanding of what it's like, how hard it might be for them, and as a result of that when they try to make a break away from the group during the race, as we know the terrain, we have a better appreciation of the race. I think it helps.' 
The event experience and the ability for the respondents to create an environment in which they could construct their own personalised experiences was a central part of the TDU. For many, it was apparent that the cycling event was not just about spectating, as pointed out by Sharon:

'It's good to be riding out into the hills of a morning as a group, having coffee somewhere and then getting to the 'King of the Mountain' stage and watching the peloton come through, have lunch, and then riding back to the hotel after that. And, in the evening we all get to sample wine in the Barossa Valley. It's great!'

The experience of being an active cyclist prior to, during, or after the professional element of the event almost led to a state of deep involvement and self-transcending experience. In the context of the TDU, the numerous comments by respondents on the positive emotions and feelings whilst riding would indicate that cyclists encountered an extraordinary experience that is different from the common pleasures of everyday life. The results from this study illustrate potential for cycling events like the TDU to generate embodied experiences in which the cycle tourist stands outside of their own self through this deep involvement, intense concentration and almost self-transcending sport tourism experience.

\section{Reinforcing identity and a sense of belonging}

In addition to illustrating the importance of bodily experiences, the interviews and observational studies also identified the ways in which event settings or 'stages' are prime locations for projecting identity (Green \& Jones, 2005; Shipway \& Jones, 2007). Cyclists experience identity through encountering the cycling events as sites of sporting significance that help to promote a sense of collective belonging. The TDU was able to deliver a sport tourism experience whereby the respondents could generate and celebrate the subculture of being an active cycle tourist, and Alan expressed views which were typical of many cyclists:

'For me, it's nice to come to a city for a week where everybody's cycling and all the cyclists have something in common, and it's nice to be around everyone in lycra.'

Brett found that he developed a whole host of new connections and friends through his chosen leisure pursuit: 
'Oh, and we've just met some people on our ride and had a coffee. It's a great way to mix with other people from other areas. We have a sort of common bond and they open up to you if you are from interstate, and they open up to you with welcome arms usually, and it's sort of a social thing.'

Keith's comments were also typical of many cyclists in this study, when he observed 'The friendship, the people you ride with and just the people from all walks of life. You have a common interest - fitness and the special achievement of riding.' Similarly, Dawn was adamant that she was always able to develop her own personal experiences through interacting with other cyclists, observing:

'We just embrace people and people come along and chat with us. Sometimes they just come and ride with us as a result of a conversation. They don't have to - there's no pressure here. We are all of a similar mind and there is no pressure - there is no control. There is no great organisation on our rides - people do what they want. I suppose it could be almost a "She'll be right attitude", but nice - not that people don't care - they do. If someone breaks down, 3 or 4 riders will stop and ask if they can help...can I do this, can I do that? We all basically look out for each other on the road. Today there were five of us, and we were looking out for the slower rider.'

Discussion between respondents in Adelaide emphasised the importance of travel, in that events like the TDU appeared to hold greater perceived capital than other cycling events in Australia. The storytelling about other events that respondents had either cycled themselves or spectated at seemed to have a dual function. Firstly, it was a key aspect of establishing the credentials of individuals within the group. Secondly it served the function of reinforcing the individual's own sense of identity (Clark \& Salaman, 1998). Through such means, identities were affirmed. Identity as a social construct is one of the key issues for sport tourism research (Shipway \& Stevenson, 2012). As such, it is suggested that this study adds to the literature in the domain of sport tourism studies with an examination of the mechanism that enable sporting participants to experience cycling at an international cycling event. As previously highlighted, these cycling 'stages' or sites symbolise aspects of cycling and present cyclists as a family with shared values, characteristics and beliefs. 
In terms of social comparisons, cyclists at the TDU were able to present their identity to others and develop this identity through demonstrating similarities between themselves and other in-group members and presenting themselves to be recognised by others in the in-group (Shipway \& Jones, 2008). Alana was a member of a Melbourne based cycling club and had developed strong friendship from cycling with others:

'Most people's jerseys tell a story about your interest in cycling; where you've been or who you ride with. I think that's handy because when you see other cyclists out riding and you see something that you recognise, it sparks a conversation.'

One comment from Edward illustrated this:

'I think the fact that we are all wearing the same gear helps identify ourselves as part of a group, and that can be a good thing because it gives us a sense of belonging. I think that's one of the things about cycling, it can be a solo experience but it can be very social, a very inclusive sort of event and if you have a uniform like everyone has, well that seems like a good thing.'

Susan was aware of the authentic nature of the TDU and how respondents were able to cocreate their own experiences:

'It's about camaraderie between cyclists generally. It makes you feel part of the pack. When you're out in the hills, you spot the jersey and point them out and say I know that group, and you do it for the camaraderie.'

As Lamont (2014b) argues, the development of communitas can not only occur amongst cycling group members but also within larger roadside crowds that gather to watch the passing professional cyclists, and an atmosphere celebrating the cycling subculture is evident. Clive was a firm advocate of the ability of a cycling event to assist with the development of a sense of communitas, and the benefits this brought to the cyclists in terms of being able to generate and celebrate a sporting subculture: 
'Well, I used to be a runner and then I fell in love with cycling through that, and then it's just the community; everybody is so friendly and you can just come here and ride for hours and hours, whereas with running it's much more intense.'

The TDU was able to provide the individual with a sense of belonging or membership to a wider social group, a place within that environment, and the subsequent opportunity to use membership of that group to enhance feelings of self-worth and self-esteem.

\section{DISCUSSION}

Findings from this study demonstrate how travel to the TDU to participate in a cycling event firstly offered a context through which to build or confirm a cycling identity (Green \& Jones, 2005); secondly, provided a time and place to interact with others who share a similar ethos of the cycling social world (Shipway et al. 2013), and thirdly, provided a sport tourism 'stage' whereby cyclists could parade and celebrate a valued social identity (Kirkup, 2012).

This unique interaction between the sport tourism stage, co-created personal experiences, meanings, identity, and belonging is encapsulated in the model for understanding sport event tourism experiences as proposed in Figure 1 which highlights how sport tourists are able to bring their social identity and their personal narratives to the interaction between active participation and spectating within the event space. The model suggests that personalised, unique experiences and meaning are constructed through 'authentic' forms of active and passive sport participation on the sport tourism stage. The model also identifies that social and physical interaction with the experience environment on the sport tourism stage is able to both reinforce and enhance the individual's own sense of social identity and belonging. These elements are discussed in more detail below.

\section{Insert Figure 1 here}

As shown in Figure 1, the sport tourism 'stage' that was of central importance to the participants and an overarching theme within the study. The results indicate that the interaction between the sport tourist and the event spaces was the central factor that provided a platform for respondents to enjoy meaningful and authentic experiences, and to reinforce a sense of identity and belonging. In doing so, this study supports some of the earliest findings 
on cycle tourism by Bull (2006) which emphasised the importance of place to racing cyclists in East Kent in England and Palmer (2010) who highlighted the impact and importance of the creation of 'Tour Spaces' in her ethnographic work on the Tour de France.

Certain cycling spaces are viewed as cycling event 'arenas' that are sacred spaces, used for the sharing of socially significant cycling experiences. As such, the results of this study have a close synergy with both Prahalad and Ramaswamy (2004) and Morgan's (2007) concept of an 'Experience Space', where the cycling event is the stage for the performance, with the cyclists acting as human props. We would suggest that this 'event space' allows an individual to maintain their cycling identities, to interact based on those identities, and to celebrate their cycling identity (Lee et al., 2014). Using Pine and Gilmore's (1999) theatrical metaphor, the findings indicate that the event proved to be the theatrical 'stage' where the cyclists create their own space to 'perform' and the cycling event provided a venue for 'drama' and theatrical production. The stories revealed from within the cycling community and social world (Shipway and Jones, 2007), engaged the cyclists emotions and aspirations within their role as cast members who were able to perform in a cycle tourism production. The sport tourism 'stage' provided the opportunity to move into a cycling space outside of the constraints and conventions of daily life in which these hedonistic impulses could be indulged (Morgan, 2007; Lee et al., 2014).

The second theme emerging from the findings results suggest that interacting with the event setting, programme and other cycle tourists through co-creative processes (Prahalad \& Ramaswamy, 2004) encouraged a more active involvement in sport event tourism which can lead to deeper, value rich experiences. Engagement with a sport tourism event such as the TDU provided an environment where individuals from diverse backgrounds were brought together around the shared values of the sport (cycling) and they could create communitas amongst other sport tourists (Shipway and Jones, 2008). Rickly-Boyd (2012b) notes that this is very similar to Turner's (1973) observations of pilgrims, whereby spontaneously, temporary communities evolve, in which individuals stripped of socio-economic attributes are treated as equals, joined by a common belief and purpose, which in the case of this study was an active involvement in cycling, as sport tourists. A key theme linked to both psychological and social benefits of sport spectatorship is the role that sport plays in linking individuals to a wider sense of community and belonging, and the associated sense of identity which this helps to provide (Wann, Melnick, Russell and Pease 2001) yet we would argue as 
an active sport participant, the opportunity to enhance both self and group esteem, such as the pride in the group to which they belong is further enhanced. Sport tourism experiences beyond active participation and spectatorship such as meeting elite cyclists in person and riding the same course helped further contribute towards a valued and enriched encounter. (Hinch \& Higham, 2005).

These findings at the TDU have resonance with the work of Lamont (2014b) on the Tour De France and the status of the French Alps as an authentic 'Tour space', and in doing so provides a useful insight into the social processes of authentication. Lamont's (2014b) findings established three main categories of social processes linked to authentication practices, which were embodied athletic performances; collective, roadside practices; and mediation of touristic encounters with place. The results from this study also suggest that cycling events like the TDU are agents for 'authentic event experiences'. Wang (1999) proposed a framework for exploring authentic experiences, and included the concept of 'existential authenticity', concerned with the state of being rather than the object. In the cycling event context, it could be suggested that cyclists judge authenticity on the basis of their own cycling experience. We would suggest that the authenticity of these distinct, extraordinary and unique cycling event experiences is assessed on the basis of the reality of the event experience, and it is the very high level of engagement of participants at cycling events that makes the TDU such a successful sports event. This suggestion has close synergy with Wang's (1999) concept that provides insight into experiences in a post-modern world, where cycling events are flourishing.

Wang (1999, p. 358) describes existential authenticity as a 'special state of being in which one is true to oneself, and acts as a counter dose to the loss of "true self" in public roles and public spheres'. Cyclists were able to search for this 'true self' at the TDU which was experienced as a liminoid space where they were less constrained by the 'roles' that they adopt in other areas of their modern lives. The results indicate that cycling events allow participants to transcend their daily lives, and one of the key aspects that allow cyclists to have authentic experiences is the high level of engagement with the very act of cycling around sections of the course. Existential authenticity has additional dimensions, including both intra-personal and inter-personal authenticity. Intra-personal authenticity is expressed through bodily feelings, and as such, is highly important for assessing cycling experiences. In cycling the body is used both in the display of personal identity in terms of health, vigour, 
movement and other physical characteristics and in all sensory perception (Higham \& Hinch, 2009). Fox, Humberstone and Dubnewick (2014) suggest that part of the attraction of cycling is connected to the bodily experience of being on, melting into, and flowing with the bicycle as it moves through what they describe as 'spacetime', that is, the embodied experience of cycling. The TDU and the places the tour passed through provided numerous opportunities for participants to have authentic existential experiences in terms of their own cycling bodily feelings.

Thirdly, the model in figure one illustrates how cycling events can act as a way of satisfying the human need for identity reinforcement (Weiss, 2001). An integral part of the cycling experience is associated with displaying special skills in cycling, and receiving approval and status from attending various cycling events, either as a participant or a spectator (also see Stebbins 1992, 2007). Like Weiss, it would be naive to think that sport is the only subsystem in society in which recognition of identity can be achieved in modern $21^{\text {st }}$ century society. However, it is suggested by Sands (2002) that there is no other social subsystem that gives so many people access to social validation and acknowledgement by others than sport, and as such, cycling events like the TDU play an important role in reinforcing a sense of identity for participants and spectators alike by providing a place to perform these roles.

In the course of everyday life, the serious cyclist will probably train on a daily basis; however, cycling is clearly mixed with work, family and other daily activities. The cyclist is therefore forced to shift between identities (Green \& Jones, 2005). In contrast, whilst at an extended cycling event like the TDU, the participants' identity as a cyclist remains central and is the identity that is presented to others (Shipway \& Jones, 2008). Cyclists were able to wear clothing and other displays of subcultural capital, and this acceptability of language, humour, social interactions and other behaviours combine to celebrate a cyclist's identity and place in the subculture. This event sport tourism space and the resulting authentic event experiences provide an important venue for these identity performances (Green, 2001).

For Green and Jones (2005), the liminoid nature of the experience works to enhance the socialization process. In the work on social identity by Jenkins (1996), he advocates the suggestions by Bourdieu (1984) who contends that social interactions are vital ways to learn the values, norms and behaviours appropriate to membership in the subculture. As such, the results of this study illustrate that cycling events are the appropriate outlet for this social 
interaction, where cyclists are in extended contact with other cyclists as distinct from everyday life. This has parallels with the work of Shipway, Holloway and Jones (2013) who examined the social world of distance runners and argue that in some social situations sports can act as a source of 'cultural capital' that might allow participants access to certain social groups, and help provide a degree of social acceptance and even respect (Crawford, 2004).. Cycling events like the TDU are able to offer the cyclist an intensive course in subcultural norms (Jenkins, 1996), and after attending cycling events, our respondents appeared to emerge with a deeper cycling identity. This event was able to provide an opportunity for self-actualisation and self-expression, which are benefits that are sometimes different from those found in everyday life.

\section{CONCLUSION}

The study intended to investigate the experiences of cycle tourists, the results of which have showed the central importance of processes of identity reinforcement as integral part of the cycling social world in event spaces. As such, the results of this study add to our understanding of the mechanisms or social processes that enabled cyclists to adopt multiple roles to experience identity through both active sports participation and spectating at sporting events. The findings support the ideas of Tsang (2000), that identity is partially created and constructed through experiences and inter-subjectivity. As cycle tourists, the respondents in this study made sense of their life experiences by performing their cycling identities alongside members of the cycling community within cycle tourism event spaces.

It would appear that the results from this study are linked to core concepts from socialanthropology. For example, understanding how meaning (for example,. the cycling identity) is created through engagement with the world (such as sport tourism and cycling), stems from social-anthropology. Likewise, concepts such as belonging based upon culture (as illustrated through the signs and symbols of cycling) and the notion of community, boundary maintenance, ritual (such as the cyclists all congregating to welcome and cheer the elite cyclists at the top of various 'mountain stages'), and myths (the stories told by cyclists) are all adding to a deeper understanding of active sport tourists. Whilst it is beyond the scope of this study to fully address the complexity of the cycling 'community', we were able to highlight and stress the importance of identification and emotional connection for our 
respondents (also see Fullager and Pavlidis 2012). The findings also help us understand how identity works through belonging to, and participating in a community of cycle tourists.

Whilst the results support the conceptualisation of Weed and Bull (2004) illustrating the unique interaction of the cyclist (the individual), the cycling environment (the cycling places) and the activity (cycling), they also illustrate that there is a further need for more focused studies that reflect the ever-increasing diversity and complexity of the interaction between sport, events and tourism. As King (2012) argues, there is a lack of research that focuses on the 'sports event space' and the embodied way in which space and place is encountered as part of the experience of sport events. The engagement of the cycle participants at the TDU was active, performative and physical. The experiences engendered a range of feelings, both physical and psychological, with an array of mostly positive emotions, including excitement and fulfilment. The results also illustrated how the sport tourism stage can be used for the cocreation of experiences and values through event programmes that allow participants to engage in cycle related activities and to interact with the event settings, other social group members (fellow cyclists), and the professional riders who made up the elite field of competitors.

The experiences highlighted the link between engagement in sport tourism and identity. At an individual level these experiences provided an opportunity for cycle tourists to form, change or confirm ideas about themselves. These experiences helped develop their sense of self, and appear to be a part of an evolving process of identity creation/confirmation. The liminal characteristics of the sport tourism stage which comprised the event setting, atmosphere, themes and daily programmes allowed cyclists to develop new and separate experiences from the everyday and in doing so; experience a degree of identity transformation. The cyclists were largely free from their daily constraints and able to focus on the activity they love (cycling), and experience new places with friends, who possessed similar intentions. However, this process was not just internally focussed and involved identification of the individual participants place within a wider group of people engaged in cycling. The results illustrated a sense of belonging to a group and the importance of that group in shaping the experience.

The paper has some practical implications for sport event organisers. Fundamentally, the results indicate that events like the TDU should be encouraged to provide activities which 
allow cyclists to co-create meaningful experiences. Given the prominence of the sport tourism 'stage', the creation of personal experiences, and the central role of identity and belonging to the respondents, it is suggested that event destinations could further create unique event settings and event designs that help to disengage participants from their daily life and to increase the emotional intensity of links with other cyclists (Lee et al, 2014). In doing so, the emphasis is also on event organisers and destinations to work collaboratively to create a distinctive event 'stage' in a host destination.

Whilst it could be suggested that this study is limited through its specific focus on a particular sport, participant and environment; as argued by Shipway and Fyall (2012), sport event experiences can only genuinely be understood by exploring the specific contexts within which they occur. This study highlights the importance of developing more nuanced approaches to understanding experience, as previously identified by Shipway and Stevenson (2012), and demonstrates that providing tourists with authentic and memorable experiences lies at the heart of what constitutes sport tourism. It is suggested that intra-personal and interpersonal authentic experiences of sport tourism, found from this study, could be further investigated to better understand experiences and its relationships with personal meanings and identity reinforcement through using either qualitative or quantitative design. It is anticipated that future studies that view sport tourism as an experience will continue to lead to a deeper understanding of the interaction between sport, events and tourism. This study illustrates that the nature of the subject area being explored, 'experiences', is one that still holds extensive future potential to further encourage interdisciplinary contributions from a diverse range of areas within the social sciences such as anthropology, cultural studies, psychology, gender studies and sociology to name but a few.

\section{REFERENCES}

Berridge, G. (2012) The promotion of cycling in London: The impact of the 2007 Tour de France Grand Depart on the image and provision of cycling in the capital, Journal of Sport and Tourism, 17 (1), 43-61.

Blamey, R.K. (1997) Ecotourism: The search for an operational definition, Journal of Sustainable Tourism, 5 (2), 109-130. 
Bourdieu, P. (1984) Distinction: A social critique of the judgement of taste. Cambridge, MA: Harvard University Press.

Bull, C.J. (2006) Racing Cyclists as Sports Tourists: The Experiences and Behaviours of a Case Study Group of Cyclists in East Kent, England, Journal of Sport and Tourism, 11 (3/4), 259-274.

Clark, T. \& Salaman, G. (1998) Telling tales: management gurus' narratives and the construction of managerial identity, Journal of Management Studies, 35 (2), 137-161.

Coghlan, A. (2012) An autoethnographic account of a cycling charity challenge event: Exploring manifest and latent aspects of the experience, Journal of Sport \& Tourism, 17 (2), $105-124$

Cox, P. (2012) Strategies promoting cycle tourism in Belgium: Practices and implications, Tourism Planning and Development, 9 (1), 25-39.

Crawford, G. (2004) Consuming Sport: Fans, Sport and Culture. London: Taylor \& Francis.

Events South Australia (2014) Our story. Retrieved 27 November 2014, from http://tourism.sa.gov.au/events.aspx

Faulks, P., Ritchie, B., \& Fluker, M. (2007) Cycle Tourism in Australia: An Investigation into its Size and Scope. Gold Coast, Australia: Sustainable Tourism CRC.

Faulks, P., Ritchie, B.W. Brown, G. \& Beeton, S. (2008) Cycle Tourism and South Australia Destination Marketing Gold Coast, Australia: Sustainable Tourism CRC.

Fox, K.M. Humberstone, B, \& Dubnewick, M. (2014) Cycling into Sensoria: Embodiment, Leisure, and Tourism, Tourism Review International, 18, 71-85.

Fullager, S. (2012) Gendered cultures of slow travel: Women's cycle touring as an alternative hedonism, in S. Fullager, K. Markwell, \& E. Wilson. Slow tourism: Experiences and mobilities, 99-112 Bristol, UK: Channel View. 
Fullager, S. \& Pavlidis, A. (2012) 'It's all about the journey': women and cycling events, International Journal of Event and Festival Management, 3(2), 149-170.

Getz, D. (2007) Event studies: Theory, research and policy for planned events. Oxford: Butterworth-Heinemann.

Gibson, H. (2005) Towards an understanding of 'why sport tourists do what they do', Sport in Society, 8(2), 198-217.

Green, B.C. (2001) Leveraging subculture and identity to promote sport events, Sport Management Review, 4(1), 1-19.

Green, C, \& Jones, I. (2005) Serious leisure, social identity and sport tourism, Sport in Society. 8 (2), 198-217.

Hallmann, K. Feiler, S, Muller, S. \& Breuer, C. (2012) The interrelationship between sport activities and the perceived winter sport experience, Journal of Sport \& Tourism, 17(2), 145163.

Higham, J. \& Hinch, T. (2009) Sport and Tourism: Globalization, Mobility and Identity. Oxford: Elsevier Butterworth Heinemann.

Hinch, T. \& Higham, J. (2005) Sport, tourism and authenticity, European Sport Management Quarterly, 5(3), pp.243-256.

Holloway, I. \& Todres, L. (2003) The status of method: flexibility, consistency and coherence, Qualitative Research, 3, pp. 345-357.

Holloway, I. and Wheeler, S. (2010) Qualitative Research in Nursing: $4^{\text {th }}$ Edition. Oxford: Blackwell Publishing.

Houge Mackenzie, S. \& Kerr, J.H. (2012) A (mis)guided adventure tourism experience: An autoethnographic analysis of mountaineering in Bolivia, Journal of Sport \& Tourism, 17(2), $125-144$. 
Jenkins, R. (1996) Social Identity. London: Routledge.

Jones, I. Brown, L. \& Holloway, I. (2013) Qualitative Research in Sport and Physical Activity. London: Sage.

Kapferer, J.N. (1997) Strategic Brand Management. London: Kogan Page.

Kirkup, N. (2012) Olympic tourists: Seeking a sense of belonging and the construction of social identities, in R. Shipway \& A. Fyall (Eds) International Sports Events: Impacts, Experiences and Identities, 169-180 London: Routledge.

King, K. (2012) Encouraging active identities and lifestyles, in R.Shipway \& A. Fyall (Eds) International Sports Events: Impacts, Experiences and Identities, 181-194 London: Routledge.

Lamont, M. (2009) Reinventing the Wheel: A definitional discussion of Bicycle Tourism, Journal of Sport and Tourism, 14 (1), 5-23.

Lamont, M. (2014a) Introduction: Cycling and Tourism, Tourism Review International, 18, $1-7$.

Lamont, M. (2014b) Authentication in sports tourism, Annals of Tourism Research, 45, pp.117.

Lamont, M. \& McKay, J. (2012) Intimations of postmodernity in sports tourism at the Tour de France, Journal of Sport and Tourism, 17 (4), 313-331.

Lee, I.S. King, K. Brown, G. \& Shipway, R. (2014, July). The nature of sport event space for social identity formation. Paper presented at Global Events Congress VI, 9-11 July 2014, Adelaide, Australia.

Lumsdon, L. (1996) Cycle tourism in Britain. Insights. March: D27-D32. 
Miller, A. (2012) Understanding the 'event experience' of active sports tourists: long distance endurance triathletes, in R. Shipway \& A. Fyall (Eds) International Sports Events: Impacts, Experiences and Identities, pp. 99-112 (London: Routledge).

Morgan, M. (2006) Making space for experiences, Journal of Retail and Leisure Property, 5 (4), 305-313.

Morgan, M. (2007) 'We're not the Barmy Army!': Reflections on the Sports Tourist Experience, International Journal of Tourism Research, 9, 361-372.

Palmer, C. (2010) 'We close towns for a living': Spatial transformation and the Tour de France, Social and Cultural Geography, 11(8), 865-881.

Pearce, P.L. \& Moscardo, G.M. (1986) The concept of authenticity in tourism experience, The Australian and New Zealand Journal of Sociology, 22 (1), 121-132.

Pine, B.J. \& Gillmore, J.H. (1999) The Experience Economy: Work is Theatre and Every Business is a Stage. Boston: HBS Press.

Prahalad, C. K. \& Ramaswamy, V. (2004) The Future of Competition: Co-Creating unique value with customers Boston: Harvard Business School Press.

Rickly-Boyd, J.M. (2012a) Lifestyle climbing: Toward existential authenticity, Journal of Sport \& Tourism, 17(2), 85-104.

Rickly-Boyd, J.M. (2012b) Authenticity and aura: A Benjaminian approach to tourism, Annals of Tourism Research, 39(1), 269-289.

Ritchie, B.W. (1999) Cycle Tourism in the South Island of New Zealand (Unpublished PhD Thesis). University of Otago, New Zealand.

Ritchie, B.W., Tkaczynski, A., \& Faulks, P. (2010) Understanding the motivation and travel behaviour of cycle tourists using involvement profiles, Journal of Travel and Tourism Marketing, 27, 409-425. 
Sands, R. (2002) Sport Ethnography Champaign, IL: Human Kinetics.

Shipway, R \& Jones, I. (2007) 'Running away from home: understanding visitor experiences and behaviour at sport tourism events', International Journal of Tourism Research, 9(5), 373-383.

Shipway, R. \& Jones, I. (2008) The Great Suburban Everest: An 'Insiders' Perspective on Experiences at the 2007 Flora London Marathon, Journal of Sport \& Tourism, 13(1), 61-77.

Shipway, R. \& Kirkup, N. (2012) The Impacts and Legacies of Sports Events, International Journal of Event and Festival Management, 3(3),1-5.

Shipway, R. \& Fyall, A. (2012). International Sports Events: Moving Toward a Future Research Agenda, in R. Shipway \& A. Fyall (Eds) International Sports Events: Impacts, Experiences and Identities, 1-10 London: Routledge.

Shipway, R. \& Stevenson, N. (2012) Experiencing Sport Tourism, Journal of Sport and Tourism, 17(2), 1-4.

Shipway, R. Holloway, I. \& Jones, I. (2013) Organisations, practices, actors and events: Exploring inside the distance running social world, International Review for the Sociology of Sport, 48(3), 259-276.

Silk, M. (2005). Sport Ethnography: Philosophy, Methodology and Reflection, in D Andrews, D. Mason \& M Silk (Eds) Qualitative methods in sports studies, 65-103 Oxford: Berg.

South Australian Tourism Commission (2005) Cycle Tourism Strategy 2005-2009. Retrieved 1 July 2014, from http://www.tourism.sa.gov.au/tourism/plan/cycley_tourism_strategy.pdf

Stebbins, R. (1992) Amateurs, Professionals and Serious Leisure. Montreal: McGill-Queen's University Press. 
Stebbins, R. (2007) Serious Leisure: A Perspective For Our Time. New Brunswick: Transaction.

Taylor, J.P. (2001) Authenticity and Sincerity in Tourism, Annals of Tourism Research, 28 (1), 7-26.

Tour Down Under (2014) Tour Down Under Information. Retrieved 24 June 2014, from http://www.tourdownunder.com.au/documents/about-the-tour/2014_Student_Information.pdf

Tsang, T. (2000) Let me tell you a story: a narrative exploration of identity in highperformance sport, Sociology of Sport Journal, 17(1), 44-59.

Turner, V. W. (1973) The center out there: Pilgrim's goal, History of Religions, 12(3), 191230.

Urry, J. (2002) The Tourist Gaze. London: Sage.

Wann, D.L. Melnick, M.J. Russell, G.W. and Pease, D.G. (2001) Sport fans: The psychology and social impact of spectators. New York: Routledge.

Wang, N. (1999) Rethinking Authenticity in Tourism Experiences, Annals of Tourism Research, 26(2), 349-370.

Weed, M. (2006) Sports tourism research 2000-2004: A systematic review of knowledge and a meta-interpretation of methods, Journal of Sport and Tourism, 11(1), 5-30.

Weed, M. and Bull, C. (2004) Sports Tourism: Participants, Policy and Providers. Oxford: Elsevier.

Weiss, O. (2001) Identity Reinforcement in Sport: Revisiting the Symbolic Interactionist Legacy, International Review for the Sociology of Sport, 36(4), 393-405. 
Table 1 - Cycle Tourist Interview Profile

\begin{tabular}{|l|l|l|l|l|l|}
\hline no & Pseudonym & Age & Gender & Residency & $\begin{array}{l}\text { Cycling Experience } \\
\text { (self-described) }\end{array}$ \\
\hline 1 & Pam & $55-64$ & Female & Cairns & Very experienced cyclist \\
\hline 2 & Susan & $55-64$ & Female & Cairns & Experienced cyclist \\
\hline 3 & Philip & $25-34$ & Male & Gold Coast & Experienced cyclist \\
\hline 4 & Edward & $45-54$ & Male & Gold Coast & Experienced cyclist \\
\hline 5 & John & $55-64$ & Male & New & Experienced cyclist \\
\hline 6 & Ian & $35-44$ & Male & Sydney & Limited cycling experience \\
\hline 7 & Andy & $55-64$ & Male & Canberra & Very experienced cyclist \\
\hline 8 & Paul & $65-74$ & Male & Canberra & Experienced cyclist \\
\hline 9 & Clive & $45-54$ & Male & Canberra & Very experienced cyclist \\
\hline 10 & Tim & $45-54$ & Male & Melbourne & Very experienced cyclist \\
\hline 11 & Sharon & $35-44$ & Female & Melbourne & Very experienced cyclist \\
\hline 12 & Trevor & $55-64$ & Male & Melbourne & Experienced cyclist \\
\hline 13 & Shaun & $35-44$ & Male & Sydney & Very experienced cyclist \\
\hline 14 & Alex & $55-64$ & Male & Sydney & Very experienced cyclist \\
\hline 15 & Dawn & $75+$ & Female & Canberra & Very experienced cyclist \\
\hline 16 & Bruce & $45-54$ & Male & Canberra & Experienced cyclist \\
\hline 17 & Alan & $35-44$ & Male & Brisbane & Experienced cyclist \\
\hline 18 & Brett & $34-45$ & Male & Melbourne & Very experienced cyclist \\
\hline 19 & Keith & $35-44$ & Male & Melbourne & Limited cycling experience \\
\hline 20 & Alana & $34-45$ & Female & Gold Coast & Very experienced cyclist \\
\hline
\end{tabular}




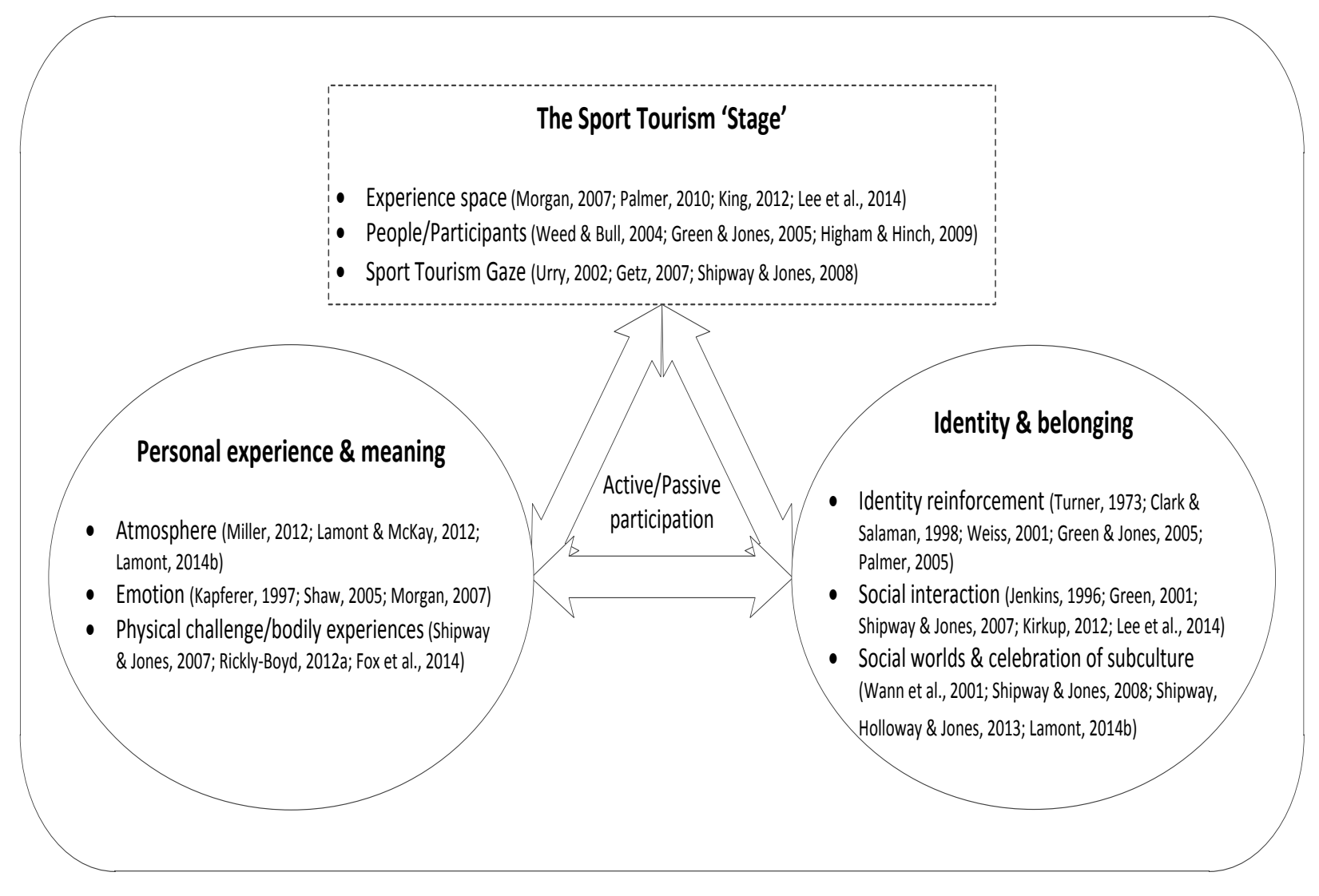

Figure 1: A model for understanding sport event tourism experiences 